\title{
BANK SAMPAH SEBAGAI ALTERNATIF STRATEGI PENGELOLAAN SAMPAH MENUJU SENTUL CITY ZERO EMISSION WASTE KABUPATEN BOGOR
}

\author{
Hasan Takbiran \\ Manajemen Lingkungan Universitas Negeri Jakarta \\ email-hasantakbiran@gmail.com
}

\begin{abstract}
Garbage cannot be separated from everyday life, from birth to death still produces waste, all of which have an impact on the environment. Educating citizens' awareness and skills for waste management by applying the principle of reducing, reusing, recycling $(3 R)$ is important in resolving waste problems through the management of waste from the source. Bank Sampah (the waste banks) Fort creation is social capital in regional waste-based management. Waste banks that are integrated with the $3 R$ principle are held at Centul City Bus Terminal, National street Centul City Bogor, Indonesia. The waste bank activity is the concept of collecting dry waste and sorting and owning management such as banking, but what is saved is not money but garbage. Empowering citizens through counseling, education, training with methods of emancipatory participation (interaction and communication), and dialogue with citizens in the community. In addition, partnership support is needed by building a network and institutional cooperation mechanism between residents of the waste bank manager and related stakeholders. The Benteng Creasi Bank Sampah has started a socialization for waste management in the Sentul City area in an effort to realize cleaner, greener, more comfortable and healthier environmental health towards the Sentul city zero emissions. In addition, integrated waste management can stimulate creativity and innovation from the community so that it can improve people's welfare.
\end{abstract}

Keywords: Bank Sampah (waste bank), environmental awareness education, regional healthbased waste management environment. 


\section{PENDAHULUAN}

Sampah tidak bisa terlepas dari kehidupan sehari-hari, dari mulai lahir sampai meninggal juga masih menghasilkan sampah, semua itu berdampak terhadap lingkungan kehidupan. Bagaimana sampah bisa terkelola dengan baik, pengelolaan sampah dari sumber dengan metode bank sampah merupakan alternatif untuk menjawab masalah tersebut. Selama ini kegiatan memilah sampah dianggap beban, tekanan, tidak bisa, repot dan itu yang sesalu muncul disetiap keluarga, memang memilah sampah itu menyusahkan dan merepotkan padahal mereka tidak sadar telah melakukan pemilahan sampah dari rumah. Di Indonesia dari Kota sampai ke Desa dari semua lapisan kehidupan masyarakat dimanapun, ternyata telah melakukan pemilahan, telah terbiasa memilah sampah contohnya ibu-ibu didapur sudah minyiapkan tempat sampah, di kamar mandi sudah punya tempat sampah. Tapi yang terjadi saat ini adalah sampah itu tatkala mau dibuang semuanya dicampur lalu di angkat ke TPA atau dibuang di sungai/saluran bahkan dibakar yang menyebabkan lingkungan menjadi kotor, timbulnya berbagai macam penyakit, pencemaran lingkungan dan kerusakan ekosistem. Faktor penyebab kurangnya kepedulian lingkungan didasari cara berfikir dan prilaku manusia. Menurut Singhirunnusorn dkk.(2012), perubahan cara berpikir masyarakat mengenai pengelolaan sampah rumah tangga untuk mengurangi sampah di sumber melalui partisipasi warga harus diintegrasikan ke dalam proyek bank sampah yang berbasis masyarakat. Sesuai dengan ketetapan dalam Undang Undang Nomor 18 Tahun 2008 tentang Pengelolaan Sampah, kini perlu perubahan cara pandang masyarakat mengenai sampah dan cara memperlakukan atau mengelola sampah. Cara pandang masyarakat pada sampah seharusnya tidak lagi memandang sampah sebagai hasil buangan yang tidak berguna.

Sampah seharusnya dipandang sebagai sesuatu yang mempunyai nilai guna dan manfaat. Penanganan sampah adalah tanggung jawab semua pihak, kita ketahui bersama bahwa setiap agama mengajarkan bagaimana cara mencintai lingkungan, Islam : Janganlah merusak di muka bumi sesudah Allah memperbaikinya. Tapi serulah Ia dengan ketakutan dan kerinduan. Sungguh rahmat Allah dekat kepada orang yang berbuat kebaikan “ (QS ;Al A'raf, 56). Kristen : "Beranakcuculah dan bertambah banyak; penuhilah bumi dan takhlukanlah itu, berkuasalah atas ikan-ikan di laut dan burung-burung di udara dan atas segala binatang yang merayap di muka bumi” (Kejadian1:28) Hindu : “Alam adalah 'Ibu Pertiwi', Ibu dari semua 
Ibu." Hindu memandang alam sebagai guru, yang memperkaya manusia dengan kearifannya. Budha: "Hiduplah di jalan yang benar dalam keselarasan dengan alam. Apabila manusia/masyarakat bertindak tidak bermoral (termasuk merusak alam) pasti akan terjadi akibat yang menyebabkan bencana alam. (Pelestarian alam adalah tugas yang harus dilaksanakan oleh semua orang). Kepedulian terhadap sampah yang kita hasilkan mulai dengan memilah sapah kita, agar sampah itu bisa terkelola secara bertanggung jawab dan dikelola secara cepat sehingga menghindari penumpukan sampah dimana-mana. Dengan edukasi akan meningkatkan partisipasi masyarakat dalam pengelolaan sampah . Pengetahuan, sikap, dan keterampilan warga mengelola sampah rumah tangga untuk melakukan daur ulang juga menjadi hal penting dalam pengelolaan sampah (Akhtar dan Soetjipto, 2014).

Setelah mengetahui, semua bertanggung jawab terhadap lingkungan terhadap penyelamatan bumi dan terhadap pencemaran sampah. Pemilahan sampah rumah tangga yang termasuk kategori sampah organik dapat dijadikan kompos sedangkan sampah rumah tangga anargonik ditabungkan ke bank sampah untuk didaur ulang kembali dan dapat dijadikan bahan yang bernilai ekonomis (Jumar dkk. 2014). Pengumpulan sampah kering dan dipilah serta memiliki manajemen layaknya perbankan, tetapi yang ditabung bukan uang melainkan sampah. Warga yang menabung (menyerahkan sampah) juga disebut nasabah dan memiliki buku tabungan serta dapat meminjam uang yang nantinya dikembalikan dengan sampah seharga uang yang dipinjam. Sampah yang ditabung akan ditimbang dan dihargai dengan sejumlah uang, kemudian akan dijual di pabrik yang sudah bekerja sama dengan bank sampah. Pendekatan yang sesuai dengan konteks masyarakat dan kesesuaian kebutuhan masyarakat menjadi kunci dari perubahan. Sementara Purba dkk. (2014) menjelaskan bahwa pengembangan bank sampah ini juga akan membantu pemerintah lokal dalam pemberdayaan masyarakat untuk mengelola sampah berbasis komunitas secara bijak dan dapat mengurangi sampah yang diangkut ke Tempat Pembuangan Akhir (TPA). Inovasi pengolahan sampah dengan program bank sampah menjadi inovasi di tingkat akar rumput yang dapat meningkatkan pendapatan masyarakat miskin perkotaan (Winarso dan Larasati, 2011). Pengelolaan menggunakan prinsip reduce, reuse dan recycle (3R). Dengan demikian pada pengembangan bank sampah Benteng Kreasi Sentul City di Kabupaten Bogor, didasari oleh beberapa permasalahan lingkungan diantaranya terjadi penumpukan sampah di beberapa titik lokasi karena pengelolaan kurang baik dan tahun ini pemerintah Kabupaten Bogor menerapkan 
Undang-Undang persampahan, setiap kawasan komersil wajib mengelola sendiri setiap sampahnya.

\section{METODE}

Program edukasi pengembangan bank sampah yang dilaksanakan di Centul City Kabupaten Bogor. Telah dilaksanakan mulai Januari 2019. Pemilihan lokasi pertama di Terminal Bis Jl. Nasional Sentul City dikarenakan merupakan wilayah yang stategis sebagai percontohan untuk diterapkan disemua kawasan Sentul City. Selain itu, kesadaran dan partisipasi masyarakat setempat menerapkan 3R dalam mengolah sampah masih rendah. Berdasarkan informasi pihak TPA, diketahui timbulan sampah Sentul City mencapai rata-rata $2000 \mathrm{~m} 3 /$ hari.

Kegiatan ini merupakan kaji terap dan edukasi masyarakat melalui pengembangan bank sampah yang dilakukan dengan menggunakan metode partisipasi-emansipatoris. Kegiatan edukasi kepada masyarakat diberikan melalui pelatihan yang diberikan berupa pelatihan wirausaha untuk mengelola bank sampah dan pelatihan daur ulang sampah menjadi produk daur ulang, baik pupuk kompos dan barang kerajinan dari sampah daur ulang. Bank sampah yang dikembangkan di Sentul City ini diberi nama Bank Sampah Benteng Kreasi yang dikelola oleh PT. Xaviera Global Synergy. Penyebaran sosialisasi berlangsung melalui media informasi disebarkan saat kegiatan rutin PKK, pengajian, dan pertemuan warga.

Secara garis besar penerapan metode dilakukan sebagaimana berikut ini, yaitu dengan melakukan pendekatan kepada warga dan stakeholders. Dengan warga dilakukan dengan interaksi dan komunikasi tatap muka melalui dialog dan pertemuan-pertemuan dengan warga di komunitas, tidak hanya pada saat kegiatan sosialisasi dan edukasi dilakukan. Dengan stakeholders dilakukan dengan mengupayakan adanya dialog dan kerja sama, khususnya pemerintah daerah setempat (di level kelurahan, kecamatan, Dinas Kebersihan dan Pertamanan Kota), pengumpul/pengepul, pengangkut/pemulung sampah, dan pengembangan kerja sama yang bersifat multi-stakeholder dengan pihak LSM maupun pihak swasta di tingkat lokal maupun regional. Sampah yang disetorkan berasal dari sampah domestik warga Sentul City yang menjadi nasabah, Penyerahan dan pengumpulan sampah dilakukan pada setiap hari sabtu dimulai sejak pukul 8 pagi hingga siang hari. Sementara untuk penimbangan sampah dilakukan oleh para petugas Bank Sampah Benteng Kreasi. 


\section{PEMBAHASAN}

Sampah menjadi salah satu permasalahan yang dialami oleh bergagai negara di dunia karena keberadaannya semakin meningkat setiap tahun, sampah terbagi tiga macam, yang pertama organik atau yang mudah diurai yang kedua anorganik atau yang sulit diurai dan yang ketia B3 (bahan beracun\& berbahaya). Ketiganya tetap menjadi masalah jika tidak dikelola dengan baik (Our Word in Data) berbagai negara di Eropa dan Amerika Utara memiliki total tumpukan sampah tinggi, cenderung memiliki resiko rendah mengalami pencemaran, polusi, maupun kerusakan lingkungan karena sampah. Data menunjukan negara-negara yang memiliki masalah dalam mengelola sampah berada di kawasan Asia Timur dan Tenggara. Indonesia termasuk yang bermasalah dalam pemhelolaan sampahnya ada sekitar 80.235 ton/hari tumpukan sampah dibuang ke Tempat Pembuangan Akhir (TPA) atau dibuang disembarang tempat . Banyak yang tidak menyadari pembuangan sampah menyebabkan efek rumah kaca, pencemaran udara, Pencemaran tanah dan air. Sehingga kualitas tanah dan air kita semakin menurun karena terus berkurang bahan organik tanah, mineral dan nutrisi. Hal ini menyebabkan lahan jadi kritis sehingga kualitas pertanian terus menurun. Juga kemampuan resapan air semakin menurun hal ini juga menjadi penyebab utama banjir.

Untuk alternatif solusi dalam mengatasi masalah sampah di perkotaan, pengembangan bank sampah merupakan kegiatan bersifat social engineering (Ridley-Duff dan Bull, 2011) yang mengajarkan masyarakat untuk memilah sampah serta menumbuhkan kesadaran masyarakat dalam pengolahan sampah. Pembentukan bank sampah harus diintegrasikan dengan gerakan program 3R sehingga warga akan memperoleh manfaat langsung, tidak hanya secara ekonomi, juga terwujudnya kesehatan lingkungan, dengan kondisi komunitas yang bersih, hijau, nyaman, dan sehat. Selain itu, bank sampah memberikan manfaat secara sosial dengan memperkuat kohesi sosial bagi keberadaan komunitas perempuan yang selama ini termarjinalisasi dalam konstruksi sosial budaya. Manfaat lainnya secara ekonomis memberi dampak berupa tambahan penghasilan, dan manfaat untuk lingkungan dapat mengurangi timbulan sampah di perkotaan. Sentul City adalah sebuah kawasan "kota pegunungan" seluas kira-kira 3000 hektare yang berada di Kecamatan Babakan Madang, Kabupaten Bogor, di sebelah timur Kota Bogor. Mengapa sentul City Peduli ; 
1. Banyaknya pembuangan sampah liar dengan perkiraan 1000 ton/hari

2. Tahun ini pemerintah Kabupaten Bogor menerapkan Undang-Undang persampahan, setiap kawasan komersil wajib mengelola sendiri setiap sampahnya.

3. Minimnya pengetahuan masyarakat dalam mengelola sampah

4. Presepsi penanganan sampah hanya menjadi tanggungjawab pemerintah

5. Tumpukan sampah di TPA terus meningkat

Selama ini Sentul City masih mengandalkan pemerintah dalah penangan sampahnya yakni dibuang ke TPA. Saat ini beluam ada pengelolaan sampah secara terpusat, baru pada tahun 2019 manajemen Sentul City berkomitmen dalam penanganan sampah dengan menggandeng pihak PT. Xaviera Global Synergi sebagai pelaksana. PT. Xaviera Global Synergy adalah perusahaan jasa kepedulian lingkungan Fokus menangani pengelolaan sampah kota, limbah Industri, limbah pertanian dan limbah peternakan. Kegiatan utama adalah mengelolah sampah yang biasanya terbuang dan menyebabkan polusi, menjadi kompos dan energi . Dengan misi mendukung ketahanan pangan, energi baru terbarukan dan penciptaan lapangan kerja berbasis sampah. Mengembangan ekonomi hijau menuju indonesia sehat, hijau dan mandiri.

Dalam rangka menuju Sentul Citi Zero Emission Waste edukasi bank sampah dan pemilahan sampah mulai diterapkan kepada warga masyarakat dan manajemen Sentul City dengan memberikan edukasi langsung maupun melaui media informasi seperti pamflet, Banner, Spanduk dan iklan lainnya. Adapun panduan dan jadwal pengangkutan sampah sebagai berikut;

Sampah organik mudah terurai seperti sisa makanan, daun, sampah buah, tulang hewan dilakukan pengangkutan setiap hari. Sampah anorganik (tidak mudah terurai) seperti plastik, kertas, logam, kaca diangkut setiap hari senin sampai kamis. Sampah B3 dan E-Waste diangkut tanggal 10 dan 15 setiap bulannya, sedangkan sampah residu seperti pembalut, kain bekas, kotoran hewan peliharaan, diapes, sampah kamar mandi diangkut setiap hari.

Program Sustainable Development.

Environment : Kebersihan, Urban Farming, Pemulihan lahan, Waste Management, Energi Baru terbarukan Kesehatan Masyarakat...Social : Pemberdayaan Masyarakat, Edukasi Masyarakat, 
Pendampingan Masyarakat. Economi : Waste Management, Integated Farming Zero Waste, Urban Farming.

Tabel 1. Perubahan kondisi sebelum dan setelah pengembangan edukasi bank sampah.

\begin{tabular}{|c|c|c|c|}
\hline No & Kondisi Sebelum & Kegiatan & Kondisi Setelah \\
\hline 1 & $\begin{array}{l}\text { Secara teknis: } \\
\text { Belum menerapkan } \\
\text { prinsip pilah di } \\
\text { sumber (3R) dan } \\
\text { belum memiliki } \\
\text { teknologi pengolahan } \\
\text { sampah }\end{array}$ & $\begin{array}{l}\text { Pemetaan masalah } \\
\text { dengan melakukan } \\
\text { pertemuan dan dialog } \\
\text { dengan pihak Sentul } \\
\text { City mengenai dampak } \\
\text { masalah sampah bagi } \\
\text { lingkungan dan } \\
\text { kesehatan warga }\end{array}$ & $\begin{array}{l}\text { Warga memiliki pengetahuan } \\
\text { mengenai dampak masalah } \\
\text { sampah, sehingga mulai terjadi } \\
\text { perubahan kebiasaan warga } \\
\text { perempuan, yang mulai aktif } \\
\text { melakukan pemilahan sampah } \\
\text { rumah tangga, dengan } \\
\text { penerapan prinsip 3R }\end{array}$ \\
\hline 2 & $\begin{array}{l}\text { Secara sosial: } \\
\text { partisipasi warga } \\
\text { rendah }\end{array}$ & $\begin{array}{l}\text { Pertemuan sosialisasi } \\
\text { kesadaran lingkungan } \\
\text { kepada warga dan } \\
\text { manajement sekaligus } \\
\text { dilakukan arahan dan } \\
\text { dialog untuk } \\
\text { memberikan } \\
\text { pengetahuan mengenai } \\
\text { kesadaran lingkungan } \\
\text { dan pembagian bibit } \\
\text { tanaman. }\end{array}$ & $\begin{array}{l}\text { Semakin banyak warga mulai } \\
\text { menyetorkan sampah ke bank } \\
\text { sampah dan berkontribusi aktif, } \\
\text { serta anggota baru yang menjadi } \\
\text { nasabah bank sampah }\end{array}$ \\
\hline 3 & $\begin{array}{l}\text { Secara ekonomi: } \\
\text { sampah dianggap } \\
\text { tidak memiliki nilai } \\
\text { ekonomi dan manfaat }\end{array}$ & $\begin{array}{l}\text { Pendataan harga dan } \\
\text { jenis sampah oleh PT. } \\
\text { Xaviera Global Synergy }\end{array}$ & $\begin{array}{l}\text { Mulai tampak perubahan } \\
\text { kondisi lingkungan secara fisik } \\
\text { dengan penurunan jumlah } \\
\text { sampah yang dibuang TPA }\end{array}$ \\
\hline
\end{tabular}

Edukasi pada warga mampuh meningkatkan partisipasi warga dalam mengelola sampah. Kehadiran bank sampah benteng kreasi menjadi salah satu alternatif dalam mengatasi masalah sampah di perkotaan Sentul City yang saat ini masih mengalami kompleksitas masalah dalam penerapannya, dikarenakan belum terintegrasi dan masih bersifat lokal. Pengembangan bank Benteng Kreasi lebih terintegrasi dengan adanya dukungan dari pemda Kabupate. Pada dasarnya intervensi pihak pemerintah daerah setempat diperlukan dalam mendukung kelancaran kegiatan serta peran pihak perusahaan/pengusaha lokal diperlukan untuk meningkatkan nilai ekonomis dari pengolahan sampah. 


\section{KESIMPULAN}

Kehadiran bank sampah Benteng Kreasi telah mendorong upaya Sentul City dalam mengatasi permasalahan lingkungan yang diterapkan oleh pemerintah Kabupaten Bogor dalam aspek pengelolaan sampah adanya selain itu terbentuknya kesadaran, pengetahuan, dan kemampuan yang mendorong partisipasi mengelola lingkungan bagi warga masyarakat. keterampilan mengelola sampah telah menstimulasi kreativitas dan inovasi kerajinan daur ulang sampah.

\section{DAFTAR PUSTAKA}

Akhtar, H., dan Soetjipto, H.P., 2014. Peran Sikap dalam Memediasi Pengaruh Pengetahuan Terhadap Perilaku Minimisasi Sampah Pada Masyarakat Terban, Yogyakarta. Jurnal Manusia dan Lingkungan, 21(3):386-392

Jumar, Fitriyah, N., dan Kalalinggie, R., 2014. Strategi Pengelolaan Sampah Rumah Tangga di Kelurahan Lok Bahu Kecamatan Sungai Kunjang Kota Samarinda. Journal Administrative Reform, 2(1):771-782

Purba, H.D., Meidiana, C., dan Adrianto, D.W., 2014. Waste Management Scenario through Community Based Waste Bank: A Case Study of Kepanjen District, Malang Regency, Indonesia. International Journal of Environmental Science and Development, 5(2):212216

Singhirunnusorn, W., Donlakorn, K., dan Kaewhanin, W., 2012. Household Recycling Behaviours and Attitudes toward Waste Bank Project: Mahasarakham Municipality. Journal of Asia Behavioural Studies, 2(6):35-47.

Winarso, H., dan Larasati, A., 2011. Dari Sampah Menjadi Upah: Inovasi Pengolahan Sampah di Tingkat Akar Rumput Kasus Program Bank Sampah "Sendu" di Kelurahan Pasar Minggu Jakarta Selatan. Jurnal Manusia dan Lingkungan, 18(1):43-59. 